\title{
Psychiatric and neurological implications in Shakespearean literature. Brief analysis
}

\author{
Julio César López-Valdés, ${ }^{1}$ Alejandro Miranda-Hernández² and Jorge Alberto Medina-Medina ${ }^{3}$ \\ ${ }^{1}$ Universidad Autónoma de Tamaulipas, Facultad de Medicina de Tampico, Tamaulipas, Mexico; ${ }^{2}$ Private Hospital, Ciudad de México, Mexico; \\ ${ }^{3}$ Instituto de Seguridad y Servicios Sociales de los Trabajadores del Estado, Hospital Regional 1 de Octubre, Ciudad de México, Mexico
}

Diseases desperate grown, By desperate alliances are relieved, Or not at all.

HAMLET, ACT IV, SCENE 3

\begin{abstract}
William Shakespeare (1564-1616) is with no doubt one of the most prolific literary artists of all times; in addition to being an eminent playwright, his works reflect arguments that express medical knowledge, allude to concise descriptions that are relevant to medical practice of that time, and even to current medicine. He wrote between 35 and 38 plays, six lyric works and 154 sonnets (approximately) where finding little more than 700 references to medicine of those days is possible. For this reason, different scholars have analyzed the medical concepts within the Shakespearean literature; some agree that these may be the result of studies of his own, while others suggest that Shakespeare repeated the medical knowledge of some "men of wisdom" of his time. It should be mentioned that the author's contemporary London society lived in an overpopulated, nauseating, sexually promiscuous city that was plagued by pests and waste and continually besieged by epidemics whose treatments many times caused greater evil than benefit (for example, lead-based make-up). Some biographers credit syphilis, alcohol, and depression as the source of Shakespeare's creative production. Despite the myriad of authors who have analyzed the insinuations about medicine in Shakespeare's dramatic accounts, Sigmund Freud (1856-1939) is perhaps the most important; throughout his career he carried out a substantial analysis of the English playwright's works owing to his passion for literature and for this author.
\end{abstract}

KEY WORDS: Shakespeare. Neurology. Cognition. Psychiatry

William Shakespeare (1564-1616) lived during the golden age of English drama (end of Elizabeth I and beginning of James I reign) and is undoubtedly one of the most prolific literary artists of all times. ${ }^{1,2}$ In addition to his literary quality, his works express medical knowledge: they contain descriptions that are relevant to medical practice of the time and even to current medicine.$^{1-4} \mathrm{~A}$ descriptive analysis of some characters allows to distinguish disorders of neurological or psychiatric nature in them; many Shakespearean heroes and antiheroes are examples of dementia, parasomnia, parkinsonism, epilepsy, migraine, palsy and even infectious diseases. ${ }^{5-9}$ At 400 years of the
Bard of Avon's death, his works continue to be a source of inspiration.

The amount of clinical data in Shakespeare's works is impressive; he wrote between 35 and 38 theatrical plays, 6 lyrical works and 154 sonnets (approximately), where finding little more than 700 references to medicine of the time is possible. ${ }^{1,10-12}$ For this reason, several researchers have analyzed the medical concepts in Shakespearean literature; some agree that they may be the result of his studies, while others indicate that Shakespeare reproduced the medical knowledge of some "men of wisdom" of his time. ${ }^{9,13}$ For example, according to Gómes, ${ }^{1}$ the
Correspondence:

Julio César López-Valdés

E-mail: jc.lopz@live.com
Date of reception: 26-02-2017

Date of acceptance: 24-09-2017

DOI://dx.doi.org/10.24875/GMM.M18000197
Gac Med Mex. 2018;154:520-523

Contents available at PubMed www.gacetamedicademexico.com 
scene where Hamlet holds Yorick's skull, the court jester, reminds of an engraving by Andreas Vesalius (15141564); in the play, the image is used to reflect on the link between life and death, as well as in recognition of wisdom acquired through ancestors.

It should be mentioned that the London society that was contemporary to the author lived in an overpopulated, nauseating and sexually promiscuous city that was crowded of pests and debris, which was continually besieged by epidemics whose treatments many times caused a greater evil than their benefit (for example, lead-based makeup)..$^{9,13-16}$ Having said that, some biographers credit syphilis, alcohol and depression as the origin of Shakespeare's creativity. ${ }^{17,18}$ Ross, ${ }^{17}$ based on the Bard's handwriting and signature, and on the countless references to sexually transmitted diseases on his texts, reinforced the following hypothesis:

A unifying diagnosis for Shakespeare's tremor, agitation and social isolation is poisoning by mercury vapor.

It is possible that Macbeth's author would have acquired this knowledge through daily life experience and reading, in addition to reflecting certain intrinsic aspects of contemporary society.

Stompe et al. ${ }^{14}$ attribute the presence of clinical characteristics consistent with madness in the Othello, Hamlet, King Lear and Macbeth fictional characters, to the sociocultural environment of the Elizabethan era. Furthermore, they suggest that after reading the plays it is possible for "melancholy" (Elizabethan term for depression), delusions and hallucinations to be identified, as well as schizophrenia, which had not yet been described as a disease.

In the same way, Montalt, ${ }^{4}$ in his series of writings, reviewed the most symbolic events for medicine that are mentioned in different Shakespearean works. Moreover, he defined some characters' conditions: depression (Hamlet), epilepsy (Julius Cesar), obsessional jealousy (Othello), dementia (Lear), addictions (Falstaff), scoliosis and psychopathy (Richard III).

On the other hand, similar to what occurs in Hamlet, insomnia, sleepwalking and nightmares become evident in Macbeth during the course of act five, even the voice of the doctor is used as a resource for direct allusion:

"A great perturbation in nature, to receive at once the benefit of sleep, and do the effects of watching". (Macbeth, act V, scene 1). ${ }^{19}$

Høyersten ${ }^{20}$ focuses on the psychotic reactions Lady Macbeth suffers in her sleep after killing the old usurer woman and her sister with an ax:
"The thane of Fife had a wife: where is she now? What, will these hands ne'er be clean?" (Macbeth, act $V$, scene 1)..$^{19}$

However, it is unquestionable that, in Shakespearian literature, Othello is one of the best descriptions of sleep disorders, since it contains a great number of allusions to the night, sleep and parasomnias:

"... The goodness of the night upon you, friends." (Othello, act I, scene 2) $)^{19}$

According to Dimsdale, ${ }^{21}$ Shakespeare was obviously aware of sexual parasomnias to have described them in detail in his tragedy. Concurrently, he affirms that Othello offers a vivid image of sleep deprivation as a tool for persuasion.

In turn, Chiu ${ }^{9}$ underscores the obsessional jealousy Othello demonstrates in large part of the play; he refers to the "Othello syndrome", a term imposed by English doctor John Todd to the psychiatric condition of sexual jealousy in an article co-authored with K. Dewhurst entitled The Othello syndrome: a study in the psychopathology of sexual jealousy (1955).

In spite of countless authors having analyzed the insinuations about medicine in the Shakespearean dramatic stories, Sigmund Freud (1856-1939) is perhaps the most important, since owing to his passion for literature and for the English dramatist, throughout his career he carried out substantial analyses of his works.

In his works The interpretation of dreams (1900) and Psychopathetic characters on the stage (1905), Freud $^{21}$ pointed out that Shakespearean literature is a reflection of self-indulgent "terror and mercy" to purge the deepest emotions and desires. Freud judiciously criticized, through psychoanalysis, what Shakespeare expressed in many of his plays; he pointed out important characteristics related to psychiatry and distinguished Hamlet as a classic model of a psychopathic figure, who suffered repressed desires to displace his father (Oedipus Rex). ${ }^{9,15,22}$

About the social resentment that Richard III openly expresses and who makes himself deserving of an "exception" that allows him to claim privileges over others owing to his distorted appearance, Freud points at this as an inherent condition of human being, who feels the need for an excuse to claim the same exemption from some social rules. ${ }^{9}$

Similarly, Freud praised the representation Ophelia offers for "melancholy" in Hamlet. ${ }^{9}$ However, he was not the first one to point out this similarity. It was English psychiatrist Hugh Welch Diamond (1809-1886) who introduced photography for the study of mental illness treatment; his work On the application of 
photography to the physiognomic and mental phenomena of insanity (1856) contains a series of patient calotypes of the Lunatic Asylum of the county of Surrey, as a representation of their illnesses. Mostly, it is about portraits of women; when observing them, it is possible to find one of these women characterized as Ophelia, a figure that was to be adopted as an image of juvenile female madness, hysteria and mental collapse..$^{23,24}$

At 400 years of Shakespeare's death, his dramaturgy and poetry are a continuous source of inspiration not only in the field of psychology and psychiatry. French neurologist Guillaume Benjamin-Amand-Duchenne (1806-1875) used the realism of emotions perceived in Macbeth to verify his studies, as he expressed it in his work Mécanisme de la physionomie humaine ou analyse électro-physiologique des passions aplicable à la pratique des arts plastiques (1862), where, in the form of an atlas, he presented a series of illustrations about facial expressions. ${ }^{23,25-27}$

Duchenne's images combine art, literature and science; given its technological superiority, he used photography to capture faces and, in some illustrations (81, 82 and 83$)$, he focused on the recreation of passages of Macbeth. ${ }^{27}$ Duchenne's intention was to reproduce the characteristic signs of violent effusions on the face of a young actress, who played Lady Macbeth, by means of electrical stimulation. ${ }^{23}$

For Jean-Martin Charcot (1825-1893), Shakespeare's work represented an educational tool for teaching. Recurrently, he used Shakespearean references in his texts and neurology sessions; he emphatically underscored how objective observation and attention to details were essential for expert clinical diagnosis. ${ }^{28,29} \mathrm{He}$ commonly used as an example a Henry VI character, Say, who throughout the played suffered tremors, which is made evident by Dick, the butcher, who asks: "Why dost thou quiver, man?", to which Say replies: "The palsy, and not fear, provokes me." Charcot, unlike his contemporaries, pointed at the origin of tremors as not characteristic of aging. ${ }^{30,31}$

When thoroughly exploring references to neurological diseases, it is possible to find allusions to Parkinsonism through the description of Shylock, a ruthless usurer in The Merchant of Venice. At the same time, contemporary prints related to the character express clinical features consistent with this condition (hypomimia, camptocormia, and pocket sign, among others).

In turn, epilepsy (falling sickness) is directly and indirectly mentioned three times in Shakespeare's plays: in Julius Caesar (act I, scene 2), Othello (act IV, scene 1) and, figuratively, in King Lear (act II, scene 2). ${ }^{32-35}$
He fell down in the marketplace, and foamed at mouth, and was speechless. (Julius Caesar, Casca, act I, scene 2). ${ }^{19}$

Although, in Othello, the disease (epilepsy) is overtly mentioned, for many authors, the surrounding situation that is narrated represents an episode of vasovagal syncope. ${ }^{34}$ Similarly, according to Collado Vázquez, ${ }^{35}$ Bergfeldt recorded 18 fainting spells in Shakespearean literature that are sometimes accompanied by convulsions; however, he himself qualifies them as vasovagal syncopes.

Remarkably, Shakespeare also had knowledge on advanced anatomy, since in three occasions he refers to the pia mater:

"... These are begot in the ventricle of memory, nourish'd in the womb of pia mater..." (Love's Labour's Lost, Holofornes, act IV, scene 2).13

In recent years, after deeply analyzing the dialogues, Matthews ${ }^{5}$ proposed a new hypothesis: that King Lear suffered from Lewy body dementia; however, there is little evidence thereof.

Finally, few works reflect in depth Shakespeare's medical knowledge extent. To delve into this topic we recommend The medical knowledge of Shakespeare (Bucknill, 1860), Shakespeare and medicine (Simpson, 1959) and The medical mind of Shakespeare (Kali, 1986).

As a final comment, imagination through medicine is an important component of the Shakespearean world and his type of writing; it is widely accepted that the Bard of Avon was unique in knowledge of the human mind, to the point that both Freud and Mahon ${ }^{36,37}$ indicate the existence of parapraxis in the dialogues, as a carefully premeditated event that reveals a double context, the purpose of which is exalting the spectator.

According to Gómes, ${ }^{1}$ Moore found the creation of words building upon the combination of other ones and syntax, which he attributed to a "neuroscience". Recently, Keidel et al. ${ }^{38}$ tried to explain this fact by means of neuroimaging studies; they concluded that the functional changes in the rhetoric used by Shakespeare elicit a surprise effect that triggers a mental reassessment of the semantic process and, in turn, an activation beyond those regions that are classically functional for typical language tasks.

For all this and more, it is possible to speak about Shakespeare as a "Renaissance neurologist". With his understanding of personality, behavior and subconscious, he has shaped our insight into human mind through ages. ${ }^{1}$ 


\section{References}

1. Gómes-Da Mota M. Shakespeare's: his $450^{\text {th }}$ birth anniversary and his insights into neurology and cognition. Arq Neuro-Psiquiatr. 2015;73:359-361.

2. Fogan L. The neurology in Shakespeare. Arch Neurol. 1989;46:922-924

3. Kail AC. The doctors in Shakespeare's plays. Part One. Aust Fam Physician. 1990;19:211-214

4. Montalt V. Shakespeare y la medicina: dramaturgias del cuerpo y la mente. Panace@. 2015;16:73-77

5. Matthews BR. Portrayal of neurological illness and physicians in the works of Shakespeare. Front Neurol Neurosci. 2010;27:216-226.

6. Paciaroni M, Bogousslavsky J. William Shakespeare's neurology. Prog Brain Res. 2013;206:3-18

7. Bogousslavsky J, Paciaroni M. Parkinsonism in poets and writers. Prog Brain Res. 2013;206:59-71.

8. Umanath S, Sarezky D, Finger S. Sleepwalking through history: medicine, arts, and courts of law. J Hist Neurosci. 2011;20:253-276.

9. Chiu C. Freud on Shakespeare: an approach to psychopathetic characters. Chang Gung Journal of Humanities and Social Sciences. 2012;5:33-56.

10. Payá E. Las enfermedades infecciosas en la obra de William Shakespeare. Rev Chil Infectol. 2013;30:660.

11. The Shakespeare Globe Trust. William Shakespeare. Londres: 2013.

12. Shakespeare: The Bard at the bedside. Lancet. 2016;387:1693.

13. Davis FM. Shakespeare's medical knowledge: how did he acquire it? The Oxfordian. 2000;3:45-58.

14. Stompe T, Ritter K, Friedmann A. Die Gestaltungen des Wahnsinns bei William Shakespeare. Wien Klin Wochenschr. 2006;118:488

15. Strachey J, Freud A, Strachey A, Tyson A. The standard edition of the complete psychological works of Sigmund Freud. Londres: Hogarth; 1953-1974.

16. Guijarro-Castro C, Estallo-Guijarro L. Cervantes y Shakespeare, dos neurólogos renacentistas. Rev Neurol. 2017;65:96.

17. Ross JJ. Shakespeare's chancre: did The Bard have syphilis? Clin Infect Dis. 2005; $40: 399-404$

18. Hanlon V. Shakespeare's tremor and Orwell's cough: the medical lives of famous writers. CMAJ. 2014;186:E67.

19. Shakespeare W. Tragedias. España: Planeta; 1994.

20. Høyersten JG. Legen, skjønnlitteraturen og den psykiatriske pasienten. Tidsskr Nor Laegeforen. 2005;125:3460-3463.
21. Dimsdale JE. Sleep in Othello. J Clin Sleep Med. 2009;5:280-281.

22. Freud S, Bunker HA. Psychopathic characters on the stage. The Tulane Drama Review. 1960;4:144-148.

23. Montilla J. llustraciones médicas de la locura femenina en el siglo XIX. En: Encuentro: artes por la integración. España: Diputación da Coruña; 2012.

24. Pérez, J. Women of the Surrey County Lunatic Asylum: first photographic portraits of mental illness (1852). Arch Womens Ment Health. 2016;19:201-202.

25. Heaton KW. Body-conscious Shakespeare: sensory disturbances in troubled characters. Med Humanit. 2011;37:97-102.

26. Fernández-Vázquez JM, Aziz-Jacobo J, Camacho-Galindo J. Guillaume Benjamín Amand Duchenne (1806-1871). El padre de la electrofisiología. Acta Ortop Mex. 2006;20:294-296.

27. Duchenne-De Boulogne GBA. Mécanisme de la physionomie humaine ou Analyse électro-physiologique de l'expression des passions applicable à la pratique des arts plastique. Francia: JB Ballière; 1876.

28. Gomes MM, Engelhardt E. Jean-Martin Charcot, father of modern neurology: an homage 120 years after his death. Arq Neuropsiquiatr. 2013;71:815-817.

29. Goetz CG. Shakespeare in Charcot's neurologic teaching. Arch Neurol. 1988;45:920-921.

30. Pahwa R, aLyons KE. Handbook of Parkinson's Disease. EE. UU.: CRC Press; 2013.

31. Finger S. Origins of neuroscience: a history of explorations into brain function. EE. UU.: MIT Press; 1994.

32. Breuer H. Images of epilepsy in Shakespeare. Medizinhist J. 2002;37:5-19.

33. Larner AJ. Neurological literature: Epilepsy. ACNR. 2007;7:16.

34. Bruschi F. Was Julius Caesar's epilepsy due to neurocysticercosis? Trends Parasitol. 2011;27:373-374.

35. Collado-Vázquez S, Carrillo JM. La epilepsia en la literatura, el cine y la televisión. Rev Neurol. 2012;55:431-442.

36. Mahon E. A parapraxis in Hamlet. A note on the aesthetic genius of William Shakespeare. Psychoanal Study Child. 1998;53:276-281.

37. Mahon E. Parapraxes in the plays of William Shakespeare. Psychoanal Study Child. 2000;55:335-370.

38. Keidel JL, Davis PM, González-Díaz V, Martín CD, Thierry G. How Shakespeare tempests the brain: neuroimaging insights. Cortex. 2013;49:913-919. 